\title{
Evaluation of hearing with pure-tone audiometry in alopecia areata patients
}

\section{Alopesia areata hastalarında saf ses odyometri ile ișitmenin değerlendirilmesi}

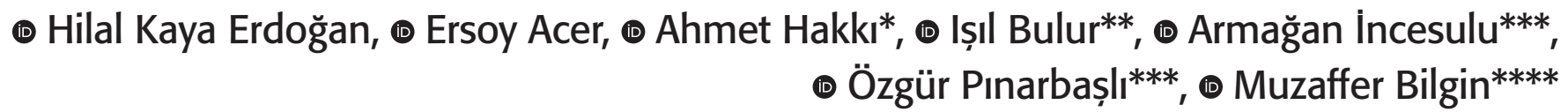

Eskișehir Osmangazi University Faculty of Medicine, Department of Dermatology, Eskișehir, Turkey *Kırșehir Ahi Evran University Faculty of Medicine, Department of Otorhinolaryngology, Kırșehir, Turkey

**Memorial Atașehir Hospital, Clinic of Dermatology, İstanbul, Turkey

***Eskișehir Osmangazi University Faculty of Medicine, Department of Otorhinolaryngology, Eskișehir, Turkey

****Eskișehir Osmangazi University Faculty of Medicine, Department of Biostatistics, Eskișehir, Turkey

\begin{abstract}
Background and Design: We aimed to evaluate whether alopecia areata (AA) patients had hearing loss with pure-tone audiometry. Materials and Methods: In the study, 48 patients with AA and 39 healthy volunteers were included. All the patients were examined by the otorhinolaryngologist and audiometric examinations were performed using a pure-tone audiometer. Pure-tone thresholds for both ears were evaluated at frequencies of $250-8000 \mathrm{~Hz}$ for air conduction.

Results: Sensorineural hypoacusis was found in $18.8 \%$ of AA patients and $10.3 \%$ of control subjects. There was no statistically significant difference between the two groups ( $p=0.422$ ). The pure-tone average for the right ear and the left ear in AA patients was $10.89 \pm 5.45$ and $10.50 \pm 5.98$, respectively. In control subjects, it was $10.25 \pm 3.43$ for the right ear and $10.23 \pm 5.46$ for the left ear. Pure-tone averages for both ears in AA patients were higher than controls; but the differences were not statistically significant ( $p=0.829$ and $p=0.526$, respectively). When we compared hearing thresholds for both ear for frequencies, there were not any significant differences between AA patients and controls $(p>0.05)$

Conclusion: There was no difference in terms of hearing loss between AA patients and healthy controls.

Keywords: Hearing loss, audiometry, alopecia areata, autoimmune, pure tone, hypoacusis

Öz

Amaç: Alopesia areata (AA) hastalarında işitme kaybı olup olmadığını saf ses odyometri ile değerlendirmeyi amaçladık.

Gereç ve Yöntem: Çalışmaya 48 AA hastası ve 39 sağlıklı gönüllü dahil edildi. Hastaların kulak burun boğaz hastalıkları uzmanı tarafından muayeneleri yapıldı. Odyometrik değerlendirme saf ses odyometrisi ile yapıldı. Her iki kulak için 250-8000 Hz frekanslarında hava yolu işitme düzeylerine bakıldı.

Bulgular: AA hastalarının \%18,8'inde, kontrol grubunun ise \%10,3'ünde sensorinöral hipoakuzi saptandı. İki grup arasındaki fark istatistiksel olarak anlamlı değildi $(p=0,422)$. Saf ses ortalaması AA hastalarında sağ kulak için $10,89 \pm 5,45$, sol kulak için $10,50 \pm 5,98$ idi. Kontrol grubunda

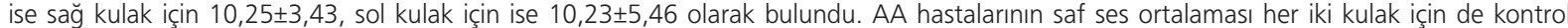
grubundan daha yüksek olmasına rağmen bu fark istatistiksel açıdan anlamlı değildi (sırasılyla $p=0,829, p=0,526)$. Her iki kulak için AA ve kontrol grubunun frekanslara göre işitme eşiği değerleri karşısş̧ıııılığında iki grup arasında istatistiksel olarak anlamlı fark görülmedi $(p>0,05)$.

Sonuç: AA hastalarında işitme kaybı yönünden kontrol grubuna göre fark saptanmadı.

Anahtar Kelimeler: Ișitme kaybı, odyometri, alopesia areata, otoimmün, saf ses, hipoakuzi
\end{abstract}

Address for Correspondence/Yazıșma Adresi: Hilal Kaya Erdoğan MD, Eskişehir Osmangazi University Faculty of Medicine, Department of Dermatology Eskişehir, Turkey Phone: +90 5057161770 E-mail: hilalkayaerdogan@yahoo.com Received/Geliș Tarihi: 28.11.2017 Accepted/Kabul Tarihi: 27.08.2018 ORCID ID: orcid.org/0000-0002-8172-1920

(c) Copyright 2019 by Turkish Society of Dermatology and Venereology

Turkderm-Turkish Archives of Dermatology and Venereology published by Galenos Yayinevi. 


\section{Introduction}

Alopecia areata (AA) is a common inflammatory disease characterized by sudden-onset hair loss'. Its pathogenesis is not clear, however, it is thought that $A A$ is a $T$ cell-mediated autoimmune disease targeting anagen phase hair follicles ${ }^{2}$. Besides, AA have been reported to be accompanied by vitiligo, systemic lupus erythematosus, psoriasis, atopic dermatitis, allergic rhinitis, autoimmune thyroid diseases, anxiety, major depression, and obsessive compulsive disorder ${ }^{1,3}$.

Sensorineural hearing loss can develop as a result of dysfunction of the inner ear, auditory nerve or auditory center. It can occur due to different etiologies, and autoimmunity is one of the possible etiologies. While the inner ear was considered to be an immune-privileged area in the past, the relationship of lymphocyte and macrophages in endolymphatic sac was suggested later, and a new era has begun for the immunology of the ear. Inflammation caused by macrophages, $T$ lymphocytes and macrophage-like melanocytes was determined to cause damage to the inner ear and result in hearing loss ${ }^{4}$.

There are many studies investigating hearing loss in various inflammatory dermatoses such as vitiligo, psoriasis, and Behçet's disease ${ }^{5-12}$. However, there has been only one study investigating the audiologic anomalies in AA patients in the literature ${ }^{13}$. In our study, we aimed to evaluate whether AA patients had hearing loss with pure-tone audiometry.

\section{Materials and Methods}

Forty-eight AA patients without hearing loss complaint were included in the study. Control group was composed of 39 sex- and age-matched healthy subjects.

Kırıkkale University Local Ethics Committee approved the study (approval number: 20/05, date: 18.08.2014). The patients were informed about the study and informed consents were taken.

Patients with diabetes mellitus, hypertension, history of head trauma, recurrent otitis media, those exposed to noise, and patients using systemic steroids, immunosuppressants and ototoxic drugs were excluded from the study. Socio-demographic characteristics of the patients, age of onset of the disease, disease duration, location, type, family history, presence of accompanying nevus flammeus, nail involvement, pre-existing stress, and accompanying diseases (autoimmune and psychiatric) were questioned.

Before audiologic examination, the patients were examined by an otorhinolaryngologist. Audiometric assessment was performed in a sound-proof cabin with a pure-tone audiometer. Pure-tone audiometry is a test that determines the hearing thresholds by giving pure-tone voices. The measurements were performed with a Resonance R37A audiometer (Italy). Air-conduction hearing thresholds were examined for both ears with $250-8000 \mathrm{~Hz}$ frequencies. After determining hearing thresholds, pure-tone averages were calculated by adding up the hearing thresholds obtained at 500-1000 and $2000 \mathrm{~Hz}$ and determining the arithmetic average. Hearing loss at $26 \mathrm{~dB}$ or above was determined as hypoacusis.

Continuous data were presented as average \pm standard deviation, while categorical data were presented in percentage (\%).

\section{Statistical Analysis}

The Shapiro-Wilk test was used for studying the compliance of data with normal distribution. The independent sample t-test was used for cases with two group numbers in the comparison of groups demonstrating normal distribution; while the Mann-Whitney $U$ test was used in cases with two group numbers in the comparison of groups that do not comply with normal distribution. Furthermore, Yates' chi-square and Fisher's exact tests were used in the analysis of the cross-tables. IBM SPSS Statistics 21.0 program was used in the analyses and a $p$ value of less than 0.05 was considered statistically significant.

\section{Results}

A total of 48 AA patients, 27 (56.3\%) men and 21 (43.8\%) women, were included in the study. The average age of the patients was $30.93 \pm 8.72$ (18-53) years. Control group consisted of 20 women (51.3\%) and 19 men (48.7\%) with ages varying between 18-60 years (average: $27.94 \pm 11.99$ ). Both groups were similar in terms of age and gender $(p=0.198, p=0.628)$.

When clinical characteristics of the patients were examined, the most common alopecia involvements were on the scalp (60.4\%) and beard $(22.9 \%)$ areas. Family history was positive in $20.8 \%$ of the patients. Six patients (12.5\%) had nail involvement, and only 1 patient (2.1\%) had nevus flammeus. Six patients had an accompanying autoimmune disease (autoimmune thyroiditis) (12.5\%), and 9 patients had an accompanying psychiatric disease (18.8\%) (8 patients had major depression and 1 patient had common anxiety disorder). Twenty-eight (58.3\%) patients described emotional stress before the development of lesions. The mean age of onset was $30.41 \pm 8.93$ (18-53) years and disease duration was 8.25 \pm 26.60 (1-180) months (Table 1).

Autoscopic examination was normal in all the patients. Sensorineural hypoacusis was determined in 9 AA patients (18.8\%) and 4 controls (10.3\%). However, the difference between the two groups was not statistically significant ( $p=0.422$ ) (Table 2 ).

When the presence of hypoacusis in both ears was compared between patient and control groups, hypoacusis was determined in the right ear in 7 AA patients (14.6\%), and 3 controls (7.7\%). For the left ear, hypoacusis was determined in 7 AA patients (14.6\%) as well and 2 subjects $(5.1 \%)$ in control group. The difference between the ears was not statistically significant either ( $p=0.501, p=0.178$ ) (Table 3 ).

In order to determine the degree of the hearing loss, we examined pure-tone averages $(250-8000 \mathrm{~Hz})$. It was $10.89 \pm 5.45$ for the right ear and $10.50 \pm 5.98$ for the left ear in AA patients. In control group, it was $10.25 \pm 3.43$ for the right ear, and $10.23 \pm 5.46$ for the left ear. Although pure-tone average in AA patients was higher than in control group for both ears, the differences were not statistically significant $(p=0.829$ and $p=0.526$, respectively). When hearing threshold values in $A A$ and control groups were compared for both ears according to frequency, no statistically significant differences were observed between the two groups ( $p>0.05$ ) (Tables 4, 5).

In AA patients, statistically significant differences were not determined when the presence of hypoacusis and audiological values of the right and left ears were compared ( $p>0.05$ ) (Table 6).

Since there were a small number of patients in each group, audiological statistical comparisons could not be performed in AA patients with regard to clinical characteristics of patients such as involvement area, nail involvement, accompanying autoimmune/psychiatric diseases. 
Table 1. Clinical characteristics of alopecia areata patients

\begin{tabular}{|c|c|c|c|}
\hline & & Frequency (n) & Percentage (\%) \\
\hline \multirow{5}{*}{ Localization } & Scalp & 29 & 60.4 \\
\hline & Beard & 11 & 22.9 \\
\hline & Scalp + beard & 5 & 10.4 \\
\hline & Eyebrow + eyelash + scalp & 2 & 4.2 \\
\hline & Eyebrow + eyelash & 1 & 2.1 \\
\hline \multirow{2}{*}{ Family history } & Yes & 10 & 20.8 \\
\hline & None & 38 & 79.2 \\
\hline \multirow{2}{*}{ Nevus flammeus } & Yes & 1 & 2.1 \\
\hline & None & 47 & 97.9 \\
\hline \multirow{2}{*}{ Nail involvement } & Yes & 6 & 12.5 \\
\hline & None & 42 & 87.5 \\
\hline \multirow{5}{*}{ Type of nail involvement } & Longitudinal striations & 2 & 4.2 \\
\hline & Onychophagy & 1 & 2.1 \\
\hline & Pitting & 1 & 2.1 \\
\hline & Trachyonychia & 1 & 2.1 \\
\hline & Transverse striations & 1 & 2.1 \\
\hline \multirow{2}{*}{ Accompanying autoimmune disease } & Yes & 6 & 12.5 \\
\hline & None & 42 & 87.5 \\
\hline \multirow{2}{*}{ Past emotional stress } & Yes & 28 & 58.3 \\
\hline & None & 20 & 41.7 \\
\hline \multirow{3}{*}{ Accompanying psychiatric disease } & Yes & 9 & 18.8 \\
\hline & None & 39 & 81.3 \\
\hline & Minimum-maximum & \multicolumn{2}{|c|}{ Mean \pm standard deviation } \\
\hline Age (years) & $18-53$ & \multicolumn{2}{|l|}{$30.93 \pm 8.72$} \\
\hline Age of onset (years) & $18-53$ & \multicolumn{2}{|l|}{$30.41 \pm 8.93$} \\
\hline Disease duration (months) & $1-180$ & \multicolumn{2}{|l|}{$8.25 \pm 26.60$} \\
\hline
\end{tabular}

Table 2. Comparison of the presence of hypoacusis in patient and control groups

\begin{tabular}{|l|l|l|l|l|}
\hline \multicolumn{2}{|c|}{} & \multicolumn{2}{|l|}{ Group n (\%) } & \multirow{2}{*}{ ₹2; p* } \\
\cline { 3 - 5 } \multicolumn{2}{|c|}{} & Patient & Control & \\
\hline \multirow{3}{*}{ Hypoacusis } & None & $39(81.3 \%)$ & $35(89.7 \%)$ & 0.644 \\
\cline { 2 - 4 } & Yes & $9(18.8 \%)$ & $4(10.3 \%)$ & 0.422 \\
\hline *Yate's chi-Square test & & \\
\hline
\end{tabular}

Table 3. Comparison of the presence of hypoacusis between both ears in patient and control groups

\begin{tabular}{|l|l|l|l|l|}
\hline \multirow{2}{*}{ Right ear } & \multicolumn{3}{|l|}{ n (\%) } & \multirow{2}{*}{ p $^{*}$} \\
\cline { 3 - 4 } & & Patient & Control & \\
\hline \multirow{2}{*}{ Hypoacusis } & None & $41(85.4 \%)$ & $36(92.3 \%)$ & \multirow{2}{*}{0.501} \\
\cline { 2 - 4 } & Yes & $7(14.6 \%)$ & $3(7.7 \%)$ & \\
\hline \multirow{2}{*}{ Left ear } & & $\mathbf{n}(\%)$ & & \multirow{2}{*}{ * } \\
\cline { 3 - 4 } & & Patient & Control & \\
\hline \multirow{2}{*}{ Hypoacusis } & None & $41(85.4 \%)$ & $37(94.9 \%)$ & \multirow{2}{*}{0.178} \\
\cline { 2 - 4 } & Yes & $7(14.6 \%)$ & $2(5.1 \%)$ & \\
\hline
\end{tabular}

*Fisher's exact test, chi-square test
Table 4. Comparison of air conduction hearing thresholds according to frequencies for right ear between patient and control group

\begin{tabular}{|c|c|c|c|}
\hline \multirow[b]{3}{*}{ Frequency } & \multicolumn{2}{|c|}{$\begin{array}{l}\text { Mean } \pm \text { standard deviation } \\
\text { Median (Q1 - Q3) }\end{array}$} & \multirow{3}{*}{$\mathbf{p}^{*}$} \\
\hline & \multicolumn{2}{|l|}{ Group } & \\
\hline & Control (dB \pm SD) & Patient $(\mathrm{dB} \pm \mathrm{SD})$ & \\
\hline 250 & $\begin{array}{l}12.44 \pm 4.42 \\
10.00(10.00-15.00)\end{array}$ & $\begin{array}{l}12.81 \pm 4.48 \\
10.00(10.00-15.00)\end{array}$ & 0.761 \\
\hline 500 & $\begin{array}{l}13.46 \pm 14.74 \\
10.00(10.00-15.00)\end{array}$ & $\begin{array}{l}10.94 \pm 5.02 \\
10.00(6.25-15.00)\end{array}$ & 0.508 \\
\hline 1000 & $\begin{array}{l}8.85 \pm 3.71 \\
10.00(5.00-10.00)\end{array}$ & $\begin{array}{l}9.38 \pm 4.57 \\
10.00(5.00-10.00)\end{array}$ & 0.877 \\
\hline 2000 & $\begin{array}{l}9.49 \pm 4.26 \\
10.00(5.00-10.00)\end{array}$ & $\begin{array}{l}9.79 \pm 6.18 \\
10.00(5.00-10.00)\end{array}$ & 0.577 \\
\hline 4000 & $\begin{array}{l}13.46 \pm 9.47 \\
10.00(10.00-15.00)\end{array}$ & $\begin{array}{l}14.58 \pm 12.24 \\
10.00(6.25-18.75)\end{array}$ & 0.853 \\
\hline 8000 & $\begin{array}{l}14.23 \pm 10.91 \\
10.00(10.00-15.00)\end{array}$ & $\begin{array}{l}17.29 \pm 15.23 \\
10.00(10.00-20.00)\end{array}$ & 0.367 \\
\hline
\end{tabular}


Table 5. Comparison of air conduction hearing thresholds according to frequencies for left ear between patient and control group

\begin{tabular}{|c|c|c|c|}
\hline Left Ear & \multicolumn{2}{|c|}{$\begin{array}{l}\text { Mean } \pm \text { standard deviation } \\
\text { Median (Q1 - Q3) }\end{array}$} & \multirow{3}{*}{$\mathbf{p}^{*}$} \\
\hline \multirow[b]{2}{*}{ Frequency } & \multicolumn{2}{|l|}{ Group } & \\
\hline & Control (dB \pm SD) & Patient ( $d B \pm S D)$ & \\
\hline 250 & $\begin{array}{l}11.92 \pm 3.56 \\
10.00(10.00-15.00)\end{array}$ & $\begin{array}{l}12.60 \pm 4.37 \\
10.00(10.00-15.00)\end{array}$ & 0.626 \\
\hline 500 & $\begin{array}{l}10.51 \pm 2.76 \\
10.00(10.00-10.00)\end{array}$ & $\begin{array}{l}10.31 \pm 4.05 \\
10.00(10.00-10.00)\end{array}$ & 0.602 \\
\hline 1000 & $\begin{array}{l}8.85 \pm 4.21 \\
10.00(5.00-10.00)\end{array}$ & $\begin{array}{l}9.38 \pm 3.94 \\
10.00(5.00-10.00)\end{array}$ & 0.785 \\
\hline 2000 & $\begin{array}{l}9.62 \pm 5.18 \\
10.00(5.00-10.00)\end{array}$ & $\begin{array}{l}9.90 \pm 5.88 \\
10.00(5.00-10.00)\end{array}$ & 0.833 \\
\hline 4000 & $\begin{array}{l}13.59 \pm 10.94 \\
10.00(10.00-15.00)\end{array}$ & $\begin{array}{l}13.54 \pm 11.11 \\
10.00(5.00-15.00)\end{array}$ & 0.504 \\
\hline 8000 & $\begin{array}{l}13.21 \pm 9.35 \\
10.00(10.00-15.00)\end{array}$ & $\begin{array}{l}14.79 \pm 15.47 \\
10.00(6.25-15.00)\end{array}$ & 0.586 \\
\hline
\end{tabular}

\section{Discussion}

Although AA is generally regarded as a benign disease, studies have shown that it affects the quality of life of patients as much as chronic skin diseases such as psoriasis and atopic dermatitis ${ }^{14}$. It is also known that both psychiatric and autoimmune diseases are observed more commonly in AA patients ${ }^{1,3}$.

The hair follicle is an immune-privileged mini organ with its own immune and hormonal microenvironment. Due to this immune privilege, it is protected against immunologic attacks. This protection is provided by the absence of MHC class I expression in anagen hair follicle ${ }^{15,16}$. This immune privilege in the hair follicle disturbed in AA. MHC I and II expression and abnormal HLA-DR antigen expression in hair follicle keratinocytes are suggested to play a key role in AA pathogenesis. In AA patients, $C D 4+T$ and $C D 8+T$ cells infiltrate the hair follicle and cause disturbances in its structure and function. Changes in the sub-groups of CD4+T cells $\left(T_{h} 1, T_{h} 2, T_{h} 17\right)$ and regulatory $T$ cells, and secretion of various cytokine and chemokines are blamed in the development of $\mathrm{AA}^{2,17}$.

Multisystem, autoimmune diseases such as Wegener granulomatosis, lupus erythematosus and polyarteritis nodosa have been demonstrated to cause sensorineural hearing loss by affecting the inner ear ${ }^{4}$. Also, there are studies in the literature on hearing abnormalities in autoimmune/ autoinflammatory dermatologic diseases such as vitiligo ${ }^{5,6}$, psoriasis $^{7-10}$ and Behçet's disease ${ }^{11,12}$.

Table 6. Comparison of pure tone averages and presence of hypoacusis in right and left ear in alopecia areata patients

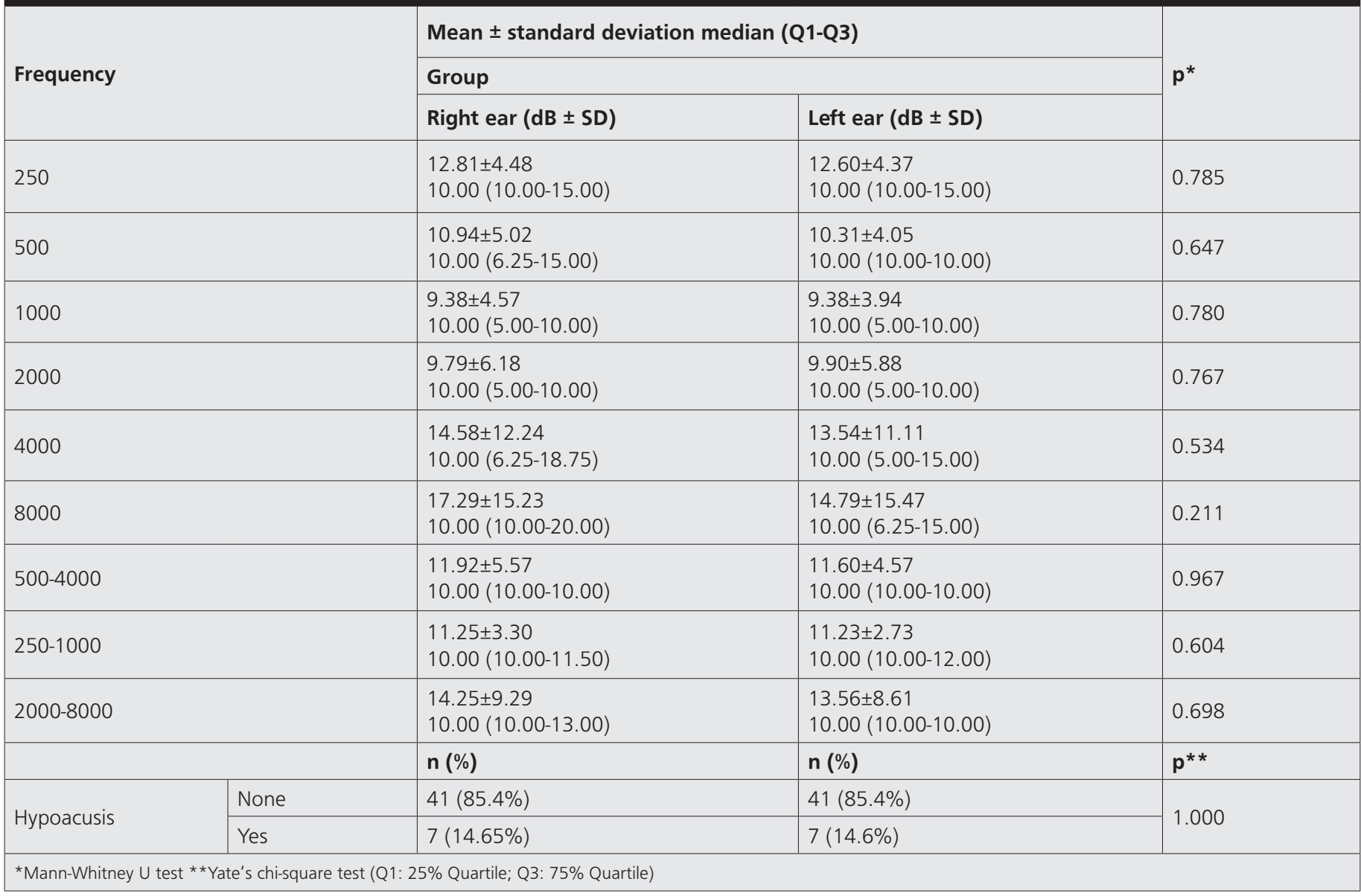


Vitiligo is an autoimmune disease characterized by the destruction of melanocytes. Aydogan et al. ${ }^{5}$ found that sensorineural hypoacusis was more common in vitiligo patients; and they suggested that melanocytes in the inner ear were important for stria vascularis and cochlea function, formation of endocochlear potentials, and ion and liquid balance between endolymph and perilymph. Likewise, in AA patients, histological and ultrastructural abnormalities in melanocytes have been shown ${ }^{18}$. Consequently, melanin may play a key role in the regulation and maintenance of the structure and function of the hearing system. The levels of proinflammatory cytokines, such as tumor necrosis factoralpha (TNF- $\alpha$ ), interleukin-1 (IL-1), IL-6 and IL-8, increase in psoriasis ${ }^{7,9}$. Wang et al. ${ }^{19}$ showed that cochlear inflammation and hearing loss decrease with TNF- $\alpha$ inhibitor etanercept. Hearing loss that can be observed in psoriasis is suggested to be related with increased levels of cytokines that may cause cochlear degeneration $7,8,10$.

There is only one study in the literature investigating the audiologic anomalies in AA patients. Ucak et al. ${ }^{13}$ found sensorineural hypoacusis in $54.9 \%$ of AA patients, and it was more frequent than in control group in a statistically significant level. They have suggested that autoimmune process may cause hearing anomalies by targeting follicular melanocytes. We found sensorineural hypoacusis in 18.8\% of AA patients; there was no statistically significant difference with control group. The difference between the study of Ucak et al. ${ }^{13}$ and our study can be explained by the patients with severe disease, long disease duration, more patients with positive family history and nail involvement in the first study.

The exact mechanism of hearing loss that is observed in AA patients is not known. Audiologic abnormalities in AA patients might originate from the autoimmune nature of AA or the increased levels of various proinflammatory cytokines, mainly TNF- $\alpha$. On the other hand, the pathologies in melanocytes in the inner ear like in vitiligo patients may be one of the reasons.

\section{Study Limitations}

It is not uncommon that sensorineural hearing loss starts from high frequencies above $8000 \mathrm{~Hz}$. Although the inner ear is affected, in early period, this effect may not reflect on pure-tone values. Limitations of our study consist of being unable to examine high frequency thresholds in patient and control groups, and being unable to perform autoacoustic emission test, that can show the effects on the inner ear in early period and can measure the outer hair cell function, due to technical insufficiencies. For these reasons, the difference between AA patients and control subjects in terms of hearing loss might not be detected exactly in our study.

\section{Conclusion}

In our study, there was no difference in terms of hearing loss between AA patients and healthy controls. In order to determine whether AA is associated with hearing loss or not; further larger-scale studies examining the relationship of AA severity and clinical characteristics with hearing loss by using high frequency audiometry, autoacoustic emission test and autoimmune-inflammatory markers are required.

\section{Ethics}

Ethics Committee Approval: Kırıkkale University Local Ethics Committee approved the study (approval number: 20/05, date: 18.08.2014).
Informed Consent: The patients were informed about the study and informed consents were taken.

Peer-review: Externally peer-reviewed.

\section{Authorship Contributions}

Surgical and Medical Practices: H.K.E., E.A., A.H., Concept: H.K.E., E.A., A.H., I.B., Design: H.K.E., E.A., A.H., I.B., Data Collection or Processing: H.K.E., E.A., A.H., Analysis or Interpretation: H.K.E., M.B., E.A., A.H., I.B., A.I., Ö.P., Literature Search: H.K.E., E.A., Writing: H.K.E., E.A.

Conflict of Interest: No conflict of interest was declared by the authors.

Financial Disclosure: The authors declared that this study received no financial support.

\section{References}

1. Chu SY, Chen YJ, Tseng WC, et al. Comorbidity profiles among patients with alopecia areata: the importance of onset age, a nationwide populationbased study. J Am Acad Dermatol 2011;65:949-56.

2. Bilgic $O$, Sivrikaya $A$, Unlu A, et al. Serum cytokine and chemokine profiles in patients with alopecia areata. J Dermatolog Treat 2016;27:260-3.

3. Chu SY, Chen YJ, Tseng WC, et al. Psychiatric comorbidities in patients with alopecia areata in Taiwan: a case-control study. Br J Dermatol 2012;166:52531.

4. Okano T. Immune system of the inner ear as a novel therapeutic target for sensorineural hearing loss. Front Pharmacol 2014;5:205.

5. Aydogan K, Turan OF, Onart S, et al. Audiological abnormalities in patients with vitiligo. Clin Exp Dermatol 2006;31:110-3.

6. Akay BN, Bozkir M, Anadolu Y, et al. Epidemiology of vitiligo, associated autoimmune diseases and audiological abnormalities: Ankara study of 80 patients in Turkey. J Eur Acad Dermatol Venereol 2010;24:1144-50.

7. Güvenç SC, Turan H, Yllmaz S, et al. Assesment of hearing loss in patients with psoriasis. Turkderm-Turk Arch Dermatol Venereology 2012;46:15-9.

8. Aydın E, Doğan B, Karabacak E, et al. Evaluation of hearing with audiometry and transient evoked otoacoustic emission in patients with mild and moderate psoriasis. Gülhane Tıp Derg 2015;57:98-101.

9. Yen $Y C$, Lin YS, Weng SF, et al. Risk of sudden sensorineural hearing loss in patients with psoriasis: a retrospective cohort study. Am J Clin Dermatol 2015;16:213-20.

10. Karabulut $H$, Karadag AS, Dagli $M$, et al. Investigation of hearing and outer hair cell function of cochlea in patients with psoriasis. Int Adv Otol 2010;6:239-44.

11. Aslan S, Serarslan G, Savas N, et al. Hearing loss in patients with Behçet's disease: an audiological and transient evoked otoacoustic emission study. J Laryngol Otol 2010;124:10-5.

12. Sonbay ND, Saka C, Tatlican S, et al. Audiological evaluation in patients with Behçet's disease. J Laryngol Otol 2014;128:694-7.

13. Ucak H, Soylu E, Ozturk S, et al. Audiological abnormalities in patients with alopecia areata. J Eur Acad Dermatol Venereol 2014;28:1045-8.

14. Liu LY, King BA, Craiglow BG. Health-related quality of life (HRQoL) among patients with alopecia areata (AA): a systematic review. J Am Acad Dermatol 2016;75:806-12.

15. Ito T. Recent Advances in the pathogenesis of autoimmune hair loss disease alopecia areata. Clin Dev Immunol 2013;2013:348546.

16. Oğuz O. Alopecia areata. Turkderm-Turk Arch Dermatol Venereology 2014;48:40-4.

17. Hordinsky M, Junqueira AL. Alopecia areata update. Semin Cutan Med Surg 2015;34:72-5.

18. Tobin DJ, Fenton DA, Kendall MD. Ultrastructural observations on the hair bulb melanocytes and melanosomes in acute alopecia areata. J Invest Dermatol 1990;94:803-7.

19. Wang $X$, Truong T, Billings PB, et al. Blockage of immune-mediated inner ear damage by etanercept. Otol Neurotol 2003;24:52-7. 